W)

\title{
First Sequence Analysis of Genes Mediating Extended-Spectrum Beta-Lactamase (ESBL) bla-TEM, SHV- and CTX-M Production in Isolates of Enterobacteriaceae in Southern Benin
}

\author{
Hornel Koudokpon ${ }^{1}$, Victorien Dougnon ${ }^{1,}{ }^{*}$, Linda Hadjadj ${ }^{2}$, Islamiath Kissira ${ }^{1}$, Brice Fanou ${ }^{1}$, Frederic \\ Loko $^{1}$, Honore Sourou Bankole ${ }^{1}$, Seydina Diene ${ }^{2}$ and Jean-Marc Rolain ${ }^{2}$ \\ ${ }^{1}$ Research Unit in Applied Microbiology and Pharmacology of Natural Substances, Research Laboratory in Applied Biology, Polytechnic School of Abomey-Calavi, University \\ of Abomey-Calavi, Cotonou, Benin \\ ${ }^{2}$ URMITE, Aix-Marseille University, 27 Bd Jean Moulin, 13385 Marseille Cedex 5, France \\ "Corresponding author: Research Unit in Applied Microbiology and Pharmacology of Natural Substances, Research Laboratory in Applied Biology, Polytechnic School of \\ Abomey-Calavi, University of Abomey-Calavi, 01 P. O. Box 2009 Cotonou, Benin. Tel: +229-97736446, Email: victorien88@hotmail.com
}

Received 2018 August 11; Accepted 2018 October 08.

\begin{abstract}
The production of extended-spectrum beta-lactamase (ESBL) by Enterobacteriaceae is a global public health problem. The present study was carried out on 156 strains of enteric bacteria isolated from urinary and cervicovaginal fluid samples. Identification of the strains was performed using MALDI-TOF MS and antibiotic susceptibility tests by disk diffusion method on Mueller Hinton agar in accordance with the recommendations of the Antibiogram Committee of the French Society for Microbiology. ESBL genes were sought by real time-polymerase chain reaction (RT-PCR) and by gel-based PCR. Gel-based PCR products were used for sequencing of the resistance genes, which were analyzed in the NCBI and Arg Annot databases. Results showed a predominance of Escherichia coli both in the urinary and cervicovaginal fluid samples. Klebsiella pneumoniae was the second most isolated bacterium in the specimens. Sensitivity to antibiotics revealed high levels of cephalosporin resistance but low resistance to carbapenem. No resistance was noted to colistine. The bla-TEM gene was present in Escherichia coli, while bla-SHV was found in Klebsiella pneumoniae and blaCTX-M was recovered in both strains. Analysis of the sequences revealed that bla-Tem1 was predominant in bla-TEM and bla-CTX-M-15 was most represented by bla-CTX-M. This study confirms the presence of ESBL-producing Enterobacteria in Benin. This was an epidemiological study aimed at detecting cephalosporin resistance in gram-negative Bacillus isolated from urinary tract and genital infections developed by women. Since the advent of molecular biology techniques for the identification of resistance in bacteria including determination of ESBL resistance genes (i.e., TEM, SHV, CTX-M), no study has been conducted to identify the different variants that circulate in Benin by sequencing these resistance genes. This sequencing is essential in order to differentiate the non-ESBL parental enzymes, which is not possible with the commonly used PCR techniques that do not permit differentiation of the point generating different variants of the ESBL genes. The present study then helped to identify those variants, in particular Tem1, SHV1, and CTX-M15, which are most encountered in Benin and around the world.
\end{abstract}

Keywords: Sequence, Analysis, ESBL, Benin, Antimicrobial Resistance

\section{Background}

Antibiotic resistance of enteric bacteria remains a major public health concern worldwide (1). Many mechanisms of resistance have been described in Enterobacteriaceae and gram-negative non-fermentative bacilli (2-4). The oldest and most persistent is the production of ESBL by these bacteria, conferring resistance to beta-lactams mainly against third-generation cephalosporin (5, 6). ESBL are enzymes produced by bacteria that hydrolyze the betalactam ring common to beta-lactam antibiotics. At the beginning of these resistances, only some genes were de- scribed, namely Tem-1, Tem2, and SHV1 $(7,8)$. However, many other types have been reported recently. Three genes are mostly involved in this resistance, including Tem, VHS, and CTX-M, which have appeared in the 2000 s $(5,9)$. This resistance usually occurs in Escherichia coli and Klebsiella pneumoniae and rarely in other enteric bacteria such as Enterobacter cloacae (10).

The present study sought to detect cephalosporin resistance in gram-negative bacilli isolated from urinary tract and genital infections in women. Since the advent of molecular biology techniques for the identification of resistance to bacteria including the determination of ESBL 
resistance genes, no study has been conducted to detect the different variants that circulate in Benin by sequencing these resistance genes. This sequencing is essential in order to differentiate the non-ESBL parental enzymes, which is not possible with the commonly used PCR techniques that do not allow the differentiation of the point mutations generating different variants of the ESBL genes. The present study aimed to identify those variants, in particular Tem1, SHV1, and CTX-M15.

In Benin, several studies have been conducted on betalactam resistance $(11,12)$, but none has examined the sequences of ESBL in order to identify the different types of ESBL that circulate in the country. The present study was initiated to bridge this molecular epidemiology gap of the ESBLs isolated in Southern Benin.

\section{Methods}

2.1. Bacterial Species Identification and Antibiotics Susceptibility

A total of 154 isolates of enteric bacteria (gramnegative Bacillus, Oxidase -) were recovered from 508 urinary and cervicovaginal fluid samples collected from three hospitals in Southern Benin, namely Bethesda Hospital, Zonal Hospital of Menontin, and the Regional Hospital of Oueme-Plateau from July to September 2015. The identification of the strains was carried out by MALDI-TOF MS (13). The susceptibility of the strains to antibiotics was examined by disk diffusion method on Mueller Hinton-2 agar (14). The antibiotic discs used were amoxicillin (AX 25), fosfomycin (FF50), ciprofloxacin (CIP5), amoxicillin + clavulanic acid (AMC30), ertapenem (ERT10), trimethoprim + sulphamethoxazol (SXT25), imipinem (IMP10), amilkacin (AK30), gentamycin (CN15), ceftriazone (CRO30), cefotaxime (CTX30), ticarcillin + sulphamethoxazol(TIM85), cefoxitin (FOX 30), rifampicin (RA 30), and aztreonam (ATM 30). Inhibition diameters were compared to those recommended by CA-SFM, 2013.

\subsection{Resistance Genes Detection}

The TEM, SHV, CTX-M genes were sought using real time and conventional polymerase chain reaction (PCR). The primers and probes as well as the positive controls used are shown in Table 1. The reaction medium was composed of $10 \mu \mathrm{L}$ QuantiTec Master Mix, $1 \mu \mathrm{L}$ Primer F, $1 \mu \mathrm{L}$ Primer R, 2 $\mu \mathrm{L}$ DNase free water, $1 \mu \mathrm{L}$ probe, and $5 \mu \mathrm{L}$ template DNA for qPCR. The reaction mixture for conventional PCR was made of 12.5 $\mu \mathrm{L}$ of QuantiTec, 0.5 $\mu \mathrm{L}$ Primer F, $0.5 \mu \mathrm{L}$ Primer R, 6.5 $\mu \mathrm{L}$ DNase free water, and $5 \mu \mathrm{L}$ DNA.

\subsection{Sequencing}

PCR products were purified and BigDye PCR was performed with the same primers. For each sample, the primers were used differently in two reactions. The reaction medium for the BigDye PCR was $3 \mu \mathrm{L}$ buffer BigDye, $2 \mu \mathrm{L}$ BigDye, $1 \mu \mathrm{L}$ primers, and $10 \mu \mathrm{L}$ DNase free water. The product of the BigDye PCR was then filtered on sephadex and subjected to gene sequencing by the Sanger method by ABI 3730 (Applied Biosystems, Foster City, CA, USA). The obtained sequences were aligned according to the primers and blasted in GenBank NCBI (http://blast.ncbi.nlm.nih.gov/) and Arg-Annot databases.

\section{Results}

Table 2 exhibits the distribution of the strains identified in MALDI-TOF. Escherichia coli was the most isolated organism in both urinary (48.7\%) and cervicovaginal fluid (11.0\%) samples, followed by Klebsiella pneumoniae (23.4\% in urinary and $3.2 \%$ in cervicovaginal fluid samples). Enterobacter cloacae was the third most isolated bacterium found only in urinary samples (9\%).

The antibiotic susceptibility pattern of the isolated enteric bacteria is depicted in Table 3. High levels of resistance were observed with beta-lactams. Proteus mirabilis, Citrobacter koseri, and Enterobacter asburiae showed low resistance compared to Escherichia coli, Klebsiella pneumoniae, and Enterobacter cloacae.

Bla-TEM was found in high proportion (57\%) followed by bla-CTX-M (16\%) and bla-SHV (18\%). Only the three bacterial species of Escherichia coli, Klebsiella pneumoniae, and Enterobacter cloacae produced ESBL. Escherichia coli produced more ESBL than the other bacteria and a single strain of Escherichia coli produced bla-SHV. On the other hand, the strains of Klebsiella pneumoniae produced more bla-SHV. About $6 \%$ of the strains carried the three ESBL genes. The carriage of CTX-M was most often associated with the presence of bla-TEM gene (Table 4).

The analysis of the sequences obtained shows a predominance of the type bla-TEM-1 for TEM, bla-SHV-1 for SHV, and bla-CTX-M-15 for CTX-M (Table 5).

\section{Discussion}

The production of ESBL by enteric bacteria is one of the most widespread forms of antibiotic resistance in the world. Out of 154 enteric bacteria isolated in three hospitals in Southern Benin, identification with MALDI-TOF revealed a high presence of Escherichia coli in both urinary (48.7\%) and cervicovaginal fluid (11\%) samples. Several studies have reported the strong involvement of Escherichia coli in urinary (15-17) and cervicovaginal infections (18-20). 


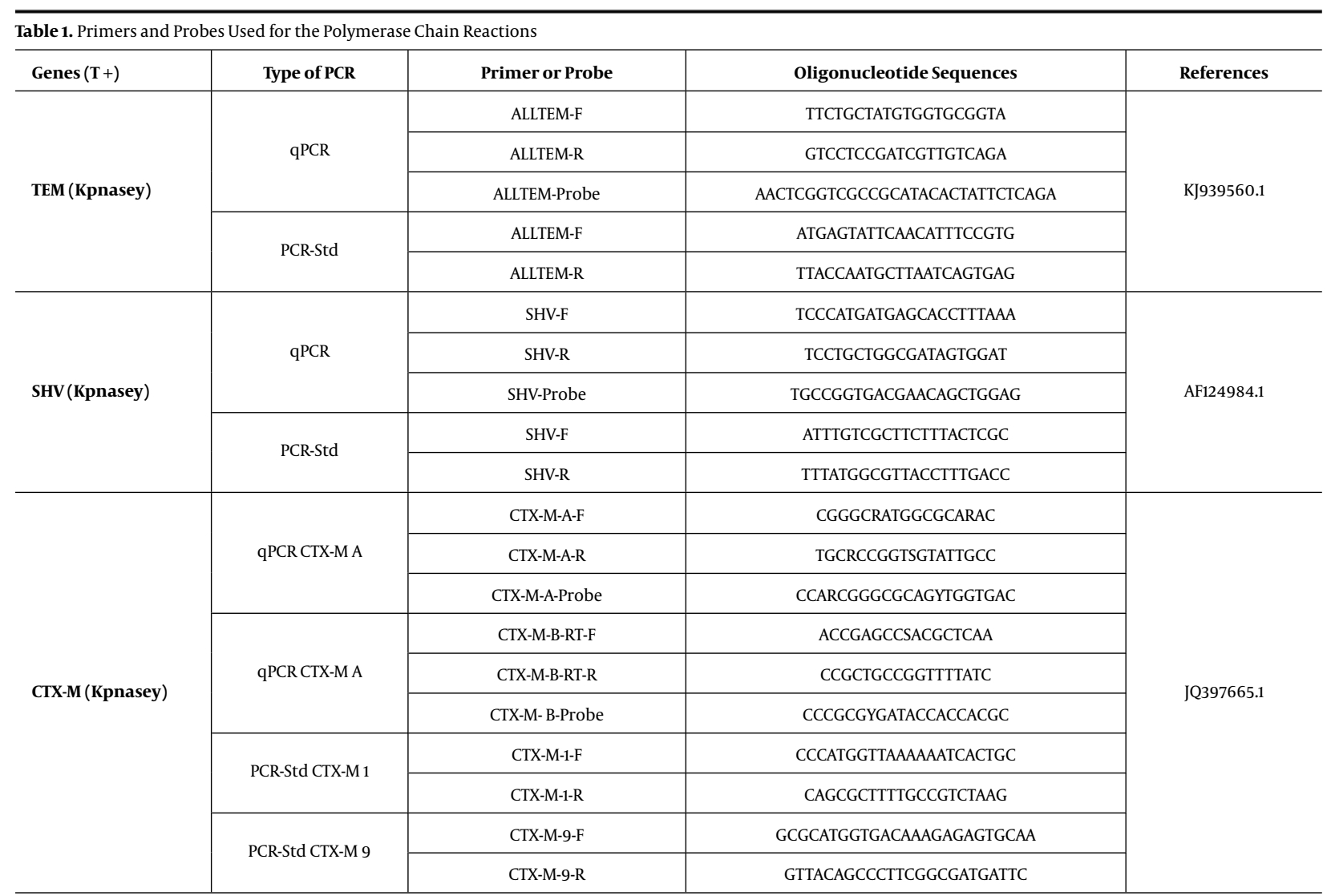

\begin{tabular}{lccc}
\hline \multicolumn{4}{l}{ Table 2. Distribution of Isolates Per Specimens ${ }^{\mathrm{a}}$} \\
\hline & Urinary & CVS & Total \\
\hline Escherichia coli & $75(48.7)$ & $17(11.0)$ & $92(59.7)$ \\
Klebsiella pneumoniae & $36(23.4)$ & $5(3.2)$ & $41(26.6)$ \\
\hline Enterobacter cloacae & $14(9.0)$ & $0(0)$ & $14(9.0)$ \\
Proteus mirabilis & $4(2.6)$ & $0(0)$ & $4(2.6)$ \\
Enterobacter asburiae & $2(1.3)$ & $0(0)$ & $2(1.3)$ \\
Citrobacter koseri & $1(0.6)$ & $0(0)$ & $1(0.6)$ \\
Total & $132(85.7)$ & $6(14.3)$ & $154(100)$ \\
\hline
\end{tabular}

Abbreviation: CVS, Cervico-vaginal secretions.

${ }^{\mathrm{a}}$ Values are expressed as No. (\%)

Klebsiella pneumoniae was the second most isolated bacterium in our specimens, which has also been reported in urinary and vaginal infections (21-23). A high resistance to cephalosporins was recorded in the present study. Nevertheless, a very low proportion of carbapenem resistance was observed. In the aminoglycoside family, we observed a high proportion of gentamicin resistance compared to a low resistance to amikacin. This discrepancy in the aminoglycoside family is attributable to the fact that amikacin has a higher minimum inhibitory concentration (MIC) and therefore, it is less used (24). This demonstrates the implication of inappropriate and non-moderate use of antibiotics in the emergence of resistances (25).

No resistance was noted to colistine, which is the last resort against infections caused by Pseudomona aeruginosa, Acinetobacter baumanii, and multidrug-resistant Enterobacteriaceae (26). It is therefore necessary to monitor the use of this antibiotic in both human and veterinary health in order to avoid resistance to this antibiotic. The bacteria that showed higher levels of resistance were Escherichia coli, Klebsiella pneumoniae, and Enterobacter cloacae. The same observation was previously made in Burkina Faso $(27,28)$.

About $65 \%$ of the enteric bacterial strains carried an ESBL gene. This prevalence of ESBL is so far the highest reported in Benin and shows high dissemination of this resistance in the country. Previous studies in Benin were based on the ESBL phenotype, which has shown deficiencies over time because bacteria that produce $\beta$-lactamases are regarded as susceptible to 3rd and 4th-generation cephalosporins (29). In addition, most of these studies are biased with the poor quality of antibiotic discs marketed 


\begin{tabular}{|c|c|c|c|c|c|c|c|c|c|c|c|c|c|c|c|}
\hline & AMX & AMC & пім & CTx & сRо & Fox & АТм & ERT & IPM & cs & АК & GEN & CIP & FF & SXT \\
\hline Escherichia coli & $\begin{array}{l}78 / 92 \\
(85 \%)\end{array}$ & $\begin{array}{l}69 / 92 \\
(74 \%)\end{array}$ & $\begin{array}{l}72 / 92 \\
(78 \%)\end{array}$ & $\begin{array}{l}23 / 92 \\
(25 \%)\end{array}$ & $\begin{array}{l}25 / 92 \\
(27 \%)\end{array}$ & $\begin{array}{l}37 / 92 \\
(40 \%)\end{array}$ & $\begin{array}{l}26 / 92 \\
(28 \%)\end{array}$ & $\begin{array}{l}7 / 92 \\
(88)\end{array}$ & $\begin{array}{l}0 / 92 \\
(0 \%)\end{array}$ & $\begin{array}{l}0 / 922 \\
(0 \%)\end{array}$ & $\begin{array}{l}2 / 92 \\
(2 \%)\end{array}$ & $\begin{array}{l}28 / 92 \\
(30 \%)\end{array}$ & $\begin{array}{l}47 / 92 \\
(512)\end{array}$ & $3 / 92(3 \%)$ & $\begin{array}{l}74 / 92 \\
(80 \%)\end{array}$ \\
\hline $\begin{array}{l}\text { Klebsiella } \\
\text { pneumoniae }\end{array}$ & $\begin{array}{c}41 / 41 \\
(100 \%)\end{array}$ & $\begin{array}{l}24 / 41 \\
(59 \%)\end{array}$ & $\begin{array}{l}22 / 41 \\
(54 \%)\end{array}$ & $\begin{array}{l}11 / 41 \\
(278)\end{array}$ & $\begin{array}{l}11 / 41 \\
(27 \%)\end{array}$ & $2 / 41(5 \%)$ & $\begin{array}{l}13 / 41 \\
(32 \%)\end{array}$ & 1/41(2\%) & $\begin{array}{l}0 / 41 \\
(0 \%)\end{array}$ & $\begin{array}{l}0 / 41 \\
(0 \%)\end{array}$ & 1/41(2\%) & $\begin{array}{l}11 / 41 \\
(27 \%)\end{array}$ & $\begin{array}{l}12 / 41 \\
(29 \%)\end{array}$ & $\begin{array}{l}0 / 41 \\
(0 \%)\end{array}$ & $\begin{array}{l}22 / 41 \\
(54 \%)\end{array}$ \\
\hline $\begin{array}{l}\text { Enterobacter } \\
\text { cloacae }\end{array}$ & $\begin{array}{l}14 / 14 \\
(100 \%)\end{array}$ & $\begin{array}{c}14 / 14 \\
(100 \%)\end{array}$ & $\begin{array}{l}11 / 14 \\
(79 \%)\end{array}$ & $\begin{array}{l}3 / 14 \\
(21 \%)\end{array}$ & $\begin{array}{l}3 / 14 \\
(21 \%)\end{array}$ & $\begin{array}{l}14 / 14 \\
(100 \%)\end{array}$ & $\begin{array}{l}6 / 14 \\
(43 \%)\end{array}$ & $\begin{array}{l}4 / 14 \\
(29 \%)\end{array}$ & $1 / 14(7 \%)$ & $\begin{array}{l}0 / 14 \\
(0 \%)\end{array}$ & $\begin{array}{l}2 / 14 \\
(14 \%)\end{array}$ & $\begin{array}{l}4 / 14 \\
(29 \%)\end{array}$ & $\begin{array}{l}3 / 14 \\
(21 \%)\end{array}$ & 1/1/4 (7\%) & $\begin{array}{l}3 / 14 \\
(21 \%)\end{array}$ \\
\hline $\begin{array}{l}\text { Proteus } \\
\text { mirabilis }\end{array}$ & $\begin{array}{l}2 / 4 \\
(50 \%)\end{array}$ & $0 / 4(0 \%)$ & $0 / 4(0 \%)$ & $0 / 4(0 \%)$ & $0 / 4(0 \%)$ & $\begin{array}{l}2 / 4 \\
(50 \%)\end{array}$ & $0 / 4(0 \%)$ & $0 / 4(0 \%)$ & $0 / 4(0 \%)$ & $\begin{array}{c}4 / 4 \\
(100 \%)\end{array}$ & $0 / 4(0 \%)$ & $0 / 4(0 \%)$ & $\begin{array}{l}2 / 4 \\
(50 \%)\end{array}$ & $1 / 4(25 \%)$ & $3 / 4(75 \%)$ \\
\hline $\begin{array}{l}\text { Enterobacter } \\
\text { asburiae }\end{array}$ & $\begin{array}{c}2 / 2 \\
(100 \%)\end{array}$ & $\begin{array}{c}2 / 2 \\
(100 \%)\end{array}$ & $0 / 2(0 \%)$ & $0 / 2(0 \%)$ & $0 / 2(0 \%)$ & $\begin{array}{c}2 / 2 \\
(100 \%)\end{array}$ & $0 / 2(0 \%)$ & $\begin{array}{c}2 / 2 \\
(100 \%)\end{array}$ & $0 / 2(0 \%)$ & $0 / 2(0 \%)$ & $0 / 2(0 \%)$ & $0 / 2(0 \%)$ & $0 / 2(0 \%)$ & $0 / 2(0 \%)$ & $\begin{array}{c}2 / 2 \\
(100 \%)\end{array}$ \\
\hline $\begin{array}{l}\text { Citrobacter } \\
\text { koseri }\end{array}$ & $\begin{array}{c}1 / 1 \\
(100 \%)\end{array}$ & $0 / 1(0 \%)$ & $0 / 1(0 \%)$ & $0 / 1(0 \%)$ & $0 / 1(0 \%)$ & $0 / 1(0 \%)$ & $0 / 1(0 \%)$ & $0 / 1(0 \%)$ & $0 / 1(0 \%)$ & $0 / 1(0 \%)$ & $0 / 1(0 \%)$ & $0 / 1(0 \%)$ & $0 / 1(0 \%)$ & $0 / 1(0 \%)$ & $0 / 1(0 \%)$ \\
\hline Total & $\begin{array}{c}138 / 154 \\
(90 \%)\end{array}$ & $\begin{array}{l}111 / 154 \\
(728)\end{array}$ & $\begin{array}{l}105 / 154 \\
(68 \%)\end{array}$ & $\begin{array}{l}37 / 154 \\
(24 \%)\end{array}$ & $\begin{array}{l}39 / 154 \\
(25 \%) \\
\end{array}$ & $\begin{array}{l}57 / 154 \\
(37 \%)\end{array}$ & $\begin{array}{l}45 / 154 \\
(29 \%)\end{array}$ & $\begin{array}{c}14 / 154 \\
(9 \%)\end{array}$ & $\begin{array}{l}1 / 154 \\
(0.6 \%)\end{array}$ & $\begin{array}{l}0 / 154 \\
(0 \%)\end{array}$ & $\begin{array}{l}5 / 154 \\
(3 \%)\end{array}$ & $\begin{array}{l}43 / 154 \\
(28 \%)\end{array}$ & $\begin{array}{c}79 / 154 \\
(51 \%)\end{array}$ & $\begin{array}{l}5 / 154 \\
(3 \%)\end{array}$ & $\begin{array}{c}104 / 154 \\
(67 \%)\end{array}$ \\
\hline & & \multicolumn{3}{|c|}{ ESBL } & TEM & \multicolumn{2}{|r|}{ SHV } & \multicolumn{2}{|l|}{ CTX-M } & TEM + SHV & \multicolumn{2}{|c|}{ TEM + CTX-M } & \multicolumn{3}{|c|}{ TEM + CTX-M + SHV } \\
\hline \multicolumn{2}{|c|}{ Escherichia coli } & \multicolumn{3}{|c|}{$68 / 92(74 \%)$} & $54 / 92(59 \%)$ & \multicolumn{2}{|c|}{$0 / 92(0 \%)$} & \multicolumn{2}{|l|}{ 1/92 (1.1\%) } & 0/92 (0\%) & \multicolumn{2}{|c|}{$14 / 92(15 \%)$} & \multicolumn{3}{|c|}{ 1/92(1.1\%) } \\
\hline \multicolumn{3}{|c|}{ Klebsiella pneumoniae } & \multicolumn{2}{|l|}{$28 / 41(68 \%)$} & $4 / 41(10 \%)$ & \multicolumn{2}{|c|}{$11 / 41(27 \%)$} & \multicolumn{2}{|l|}{$1 / 41(2.5 \%)$} & $2 / 41(5 \%)$ & \multicolumn{2}{|c|}{$3 / 41(7.5 \%)$} & \multicolumn{3}{|c|}{$8 / 41(20 \%)$} \\
\hline \multicolumn{3}{|c|}{ Enterobacter cloacae } & \multicolumn{2}{|l|}{$4 / 16(25 \%)$} & $1 / 16(6 \%)$ & \multicolumn{2}{|c|}{$2 / 16(12 \%)$} & \multicolumn{2}{|l|}{$0 / 16(0 \%)$} & 1/16(6\%) & \multicolumn{2}{|c|}{ 0/16 (0\%) } & \multicolumn{3}{|c|}{$0 / 16(0 \%)$} \\
\hline \multicolumn{2}{|l|}{ Total } & \multicolumn{3}{|c|}{$100 / 154(64 \%)$} & $59 / 154(38 \%)$ & & /154 (8\%) & $2 / 154(1 \%)$ & & $3 / 154(2 \%)$ & & $44(11 \%)$ & & $9 / 154(6 \%$ & \\
\hline & & & Тур & & & o. $(\%)$ & & E.col & & & K. pneun & miae & & E. cloace & \\
\hline & & & Ten & $\mathrm{n} 1$ & & $3(94)$ & & $65 / 88(7$ & $72 \%)$ & & $17 / 88(2$ & & & $1 / 88(1 \%)$ & \\
\hline Bla Tem & & & Tem & & & 3(3) & & $3 / 88(3$ & & & $0 / 88($ & & & $0 / 88(0 \%)$ & \\
\hline & & & Tem & & & $2(2)$ & & $1 / 88(19$ & & & $0 / 88($ & & & $1 / 88(1 \%)$ & \\
\hline Bla CTX-M & & & CTX-N & M 15 & & $4(89)$ & & $12 / 28(4$ & & & $12 / 28($ & & & $0 / 28(0 \%)$ & \\
\hline & & & Othe & & & $4(11)$ & & $4 / 28(14$ & & & $0 / 28($ & & & $0 / 28(0 \%)$ & \\
\hline & & & SHV & & & $5(60)$ & & $0 / 25(0$ & & & $11 / 25(4$ & & & $2 / 25(8 \%)$ & \\
\hline Bla SHV & & & SHV & & & $3(32)$ & & $1 / 25(4$ & & & $8 / 25(3$ & & & $1 / 25(4 \%)$ & \\
\hline & & & SHV & & & $2(8)$ & & $0 / 25(0$ & & & $2 / 25($ & & & $0 / 25(0 \%)$ & \\
\hline
\end{tabular}

in Benin (30).

This study also revealed the presence of bla-TEM in Escherichia coli and bla-SHV in Klebsiella pneumoniae. Anago et al. (11) also reported a high presence of bla-Tem in Escherichia coli strains isolated from nosocomial infections in Southern Benin. Hou et al. (31) reported high proportions of bla-SHV in Klebsiella pneumoniae strains compared to bla-Tem in China. The natural production of penicillinase by Klebsiella pneumoniae strains encoding a gene with SHV, LEN, and OKP variants explains the presence of SHV in Klebsiella pneumoniae strains (32). Kamga et al. (33) observed a strong presence of TRI (inhibitor-resistant TEM) in Escherichia coli strains, which may justify the high presence of TEM in the Escherichia coli strains isolated in the present study. Zongo et al. (28) in Burkina Faso, Salah (34), and Diagbouga et al. (35) in Togo also found that the bla-
Tem gene was the most widespread in ESBL-producing Escherichia coli strains, whereas Bla-SHV was the predominant gene in ESBL-producing Klebsiella pneumonia strains. However, the high proportion of bla-CTX-M in Togo (95.7\%) and Burkina Faso (65.49\%) is not the same as in our study because this gene came second after bla-Tem and represented only $18 \%$.

The molecular typing of the various resistance genes revealed the presence of three types of Bla-TEM including bla-TEM1 (83/88), bla-TEM2 (3/88), and bla-TEM54 (2/88). BlaCTX-M15 was the most represented type of bla-CTX-M. The strong presence of this type has been reported in many studies in Africa and worldwide (27, 36-41). SHV-1 was the predominant VHS in our study followed by $S H V-12$ and $S H V$ 2. These types have also been reported in (42-45) as well. 


\subsection{Conclusion}

The present study revealed the strong presence of ESBLproducing Enterobacteriaceae in Benin. It remains the most dominant resistance to beta-lactam and evolves towards resistance to carbapenems. The types of ESBL gene reported in the study are widely replicated in Africa and are implicated in many infectious pathologies. There is an urgent need to devise policies towards reducing antimicrobial resistance in Africa in order to reduce mortality and the high cost of treatment associated with ESBL-producing Enterobacteriaceae.

\section{Acknowledgments}

We thank Edgarthe Priscilla Ngaiganam for technical assistance, Stephanie Lepage for her expertise in antimicrobial susceptibility, and the URMAPha team for sample collection.

\section{Footnote}

Authors' Contribution: All authors equally contribute to the study.

\section{References}

1. World Health Organization . Antimicrobial resistance global report on surveillance. World Health Organization; 2014. 256 p.

2. Raji MA, Jamal W, Ojemhen O, Rotimi VO. Point-surveillance of antibiotic resistance in Enterobacteriaceae isolates from patients in a Lagos Teaching Hospital, Nigeria. J Infect Public Health. 2013;6(6):431-7. doi: 10.1016/j.jiph.2013.05.002. [PubMed: 23999335].

3. Leski TA, Taitt CR, Bangura U, Stockelman MG, Ansumana R, Cooper $\mathrm{WH}$ 3rd, et al. High prevalence of multidrug resistant Enterobacteriaceae isolated from outpatient urine samples but not the hospital environment in Bo, Sierra Leone. BMC Infect Dis. 2016;16:167. doi: 10.1186/s12879-016-1495-1. [PubMed: 27090787]. [PubMed Central: PMC4836052].

4. Ruppe E, Armand-Lefevre L, Estellat C, Consigny PH, El Mniai A, Boussadia $Y$, et al. High rate of acquisition but short duration of carriage of multidrug-resistant enterobacteriaceae after travel to the tropics. Clin Infect Dis. 2015;61(4):593-600. doi: 10.1093/cid/civ333. [PubMed: 25904368].

5. Cantó R, Coque TM, Baquero F, Rice LB. The ctx-m b-lactamase pandemic this review comes from a themed issue on antimicrobials edited. Curr Opin Microbiol. 2006;9:466-75.

6. Okesola AO, Makanjuola O. Resistance to third-generation cephalosporins and other antibiotics by enterobacteriaceae in Western Nigeria. Am J Infect Dis. 2009;5(1):17-20. doi: 10.3844/ajidsp.2009.17.20

7. Abdallah HM, Reuland EA, Wintermans BB, Al Naiemi N, Koek A, Abdelwahab AM, et al. Extended-spectrum beta-lactamases and/or carbapenemases-producing enterobacteriaceae isolated from retail chicken meat in Zagazig, Egypt. PLoS One. 2015;10(8). e0136052. doi 10.1371/journal.pone.0136052. [PubMed: 26284654]. [PubMed Central: PMC4540287]

8. Paterson DL, Bonomo RA. Extended-spectrum beta-lactamases: A clinical update. Clin Microbiol Rev. 2005;18(4):657-86. doi: 10.1128/CMR.18.4.657-686.2005. [PubMed:16223952]. [PubMed Central: PMC1265908].
9. Valverde A, Turrientes MC, Norman F, San Martin E, Moreno L, Perez-Molina JA, et al. CTX-M-15-non-ST131 Escherichia coli isolates are mainly responsible of faecal carriage with ESBL-producing Enterobacteriaceae in travellers, immigrants and those visiting friends and relatives. Clin Microbiol Infect. 2015;21(3):252 e1-4. doi: 10.1016/j.cmi.2014.09.021. [PubMed: 25658550].

10. Mathers AJ, Peirano G, Pitout JD. The role of epidemic resistance plasmids and international high-risk clones in the spread of multidrugresistant Enterobacteriaceae. Clin Microbiol Rev. 2015;28(3):565-91. doi: 10.1128/CMR.00116-14. [PubMed: 25926236]. [PubMed Central: PMC4405625].

11. Anago E, Ayi-Fanou L, Akpovi CD, Hounkpe WB, Agassounon-Djikpo Tchibozo M, Bankole HS, et al. Antibiotic resistance and genotype of beta-lactamase producing Escherichia coli in nosocomial infections in Cotonou, Benin. Ann Clin Microbiol Antimicrob. 2015;14:5. doi: 10.1186/s12941-014-0061-1. [PubMed: 25595314]. [PubMed Central: PMC4304606].

12. Ahoyo AT, Baba-Moussa L, Anago AE, Avogbe P, Missihoun TD, Loko F, et al. [Incidence of infections dues to Escherichia coli strains producing extended spectrum betalactamase, in the Zou/Collines Hospital Centre (CHDZ/C) in Benin]. Med Mal Infect. 2007;37(11):746-52. French. doi: 10.1016/j.medmal.2007.03.004. [PubMed: 17434702]

13. Seng P, Abat C, Rolain JM, Colson P, Lagier JC, Gouriet F, et al. Identification of rare pathogenic bacteria in a clinical microbiology laboratory: Impact of matrix-assisted laser desorption ionizationtime of flight mass spectrometry. J Clin Microbiol. 2013;51(7):218294. doi: 10.1128/JCM.00492-13. [PubMed: 23637301]. [PubMed Central: PMC3697718].

14. CA-SFM . Recommandations EUCAST pour la réalisation de l'Antibiogramme. Société Française Microbiol. 2017;1:128. French.

15. Rossignol L, Vaux S, Maugat S, Blake A, Barlier R, Heym B, et al. Incidence of urinary tract infections and antibiotic resistance in the outpatient setting: A cross-sectional study. Infection. 2017;45(1):33-40. doi: 10.1007/s15010-016-0910-2. [PubMed: 27234045].

16. Mann R, Mediati DG, Duggin IG, Harry EJ, Bottomley AL. Metabolic adaptations of uropathogenic E. coli in the urinary tract. Front Cell Infect Microbiol. 2017;7:241. doi: 10.3389/fcimb.2017.00241. [PubMed: 28642845]. [PubMed Central: PMC5463501].

17. Fedrigo NH, Mazucheli J, Albiero J, Shinohara DR, Lodi FG, Machado A, et al. Pharmacodynamic evaluation of fosfomycin against Escherichia coli and Klebsiella spp. from urinary tract infections and the influence of $\mathrm{pH}$ on fosfomycin activities. Antimicrob Agents Chemother. 2017;61(8). doi: 10.1128/AAC.02498-16. [PubMed: 28607025]. [PubMed Central: PMC5527594].

18. Kazi YF, Saleem S, Kazi N. Investigation of vaginal microbiota in sexually active women using hormonal contraceptives in Pakistan. BMC Urol. 2012;12:22. doi: 10.1186/1471-2490-12-22. [PubMed: 22901000]. [PubMed Central: PMC3492163]

19. Ghartey JP, Carpenter C, Gialanella P, Rising C, McAndrew TC, Mhatre $\mathrm{M}$, et al. Association of bactericidal activity of genital tract secretions with Escherichia coli colonization in pregnancy. Am J Obstet Gynecol. 2012;207(4):297 e1-8. doi: 10.1016/j.ajog.2012.07.025. [PubMed: 22867687]. [PubMed Central: PMC3462306].

20. Ghartey JP, Smith BC, Chen Z, Buckley N, Lo Y, Ratner AJ, et al. Lactobacillus crispatus dominant vaginal microbiome is associated with inhibitory activity of female genital tract secretions against Escherichia coli. PLoS One. 2014;9(5). e96659. doi: 10.1371/journal.pone.0096659. [PubMed: 24805362]. [PubMed Central: PMC4013016].

21. Shakya P, Shrestha D, Maharjan E, Sharma VK, Paudyal R. ESBL production among E. coli and Klebsiella spp. causing urinary tract infection: a hospital based study. Open Microbiol J. 2017;11:23-30. doi: 10.2174/1874285801711010023. [PubMed: 28553414]. [PubMed Central: PMC5427687]. 
22. Boix-Palop L, Xercavins M, Badia C, Obradors M, Riera M, Freixas $\mathrm{N}$, et al. Emerging extended-spectrum beta-lactamase-producing Klebsiella pneumoniae causing community-onset urinary tract infections: A case-control-control study. Int J Antimicrob Agents. 2017;50(2):197-202. doi: 10.1016/j.ijantimicag.2017.03.009. [PubMed: 28552471]

23. Yang X, Yang J, Wang H, Li C, He Y, Jin S, et al. Normal vaginal bacterial flora of giant pandas (ailuropoda melanoleuca) and the antimicrobial susceptibility patterns of the isolates. J Zoo Wildl Med. 2016;47(2):671-5. doi: 10.1638/2015-0203a.1. [PubMed: 27468049].

24. Gauzit R. [Latest developments in antibiotherapy-Aminoglycosides, again and again: Correct use and therapeutic monitoring]. Réanimation. 2010;20(S2):290-8. French. doi: 10.1007/s13546-010-0106-1.

25. Dosso M, Bissagnene E, Coulibaly M, Paye HK, N'Douba A, Guessennd $\mathrm{N}$, et al. [Acquired resistance and prescription of antibiotics in Africa: A critical assessment]. Médecine et Maladies Infectieuses. 2000;30:s197204. French. doi:10.1016/s0399-077x(00)89090-3.

26. Rhouma M, Beaudry F, Theriault W, Letellier A. Colistin in pig production: Chemistry, mechanism of antibacterial action, microbial resistance emergence, and one health perspectives. Front Microbiol. 2016;7:1789. doi: 10.3389/fmicb.2016.01789. [PubMed: 27891118]. [PubMed Central: PMC5104958].

27. Ouedraogo AS, Sanou M, Kissou A, Sanou S, Solare H, Kabore F, et al. High prevalence of extended-spectrum ss-lactamase producing enterobacteriaceae among clinical isolates in Burkina Faso. BMC Infect Dis. 2016;16:326. doi: 10.1186/s12879-016-1655-3. [PubMed: 27400864]. [PubMed Central: PMC4939587].

28. Zongo KJ, Metuor Dabire A, Compaore LG, Sanou I, Sangare L, Simpore J, et al. First detection of bla TEM, SHV and CTX-M among gram negative bacilli exhibiting extended spectrum -lactamase phenotype isolated at University Hospital Center, Yalgado Ouedraogo, Ouagadougou, Burkina Faso. Afr J Biotechnol. 2015;14(14):1174-80. doi: 10.5897/ajb2014.13908.

29. CA-SFM . Recommandations EUCAST pour la réalisation de l'Antibiogramme. Société Française Microbiol. 2015;2:117.

30. Dougnon T, Johnson R, Bankole H, Koudjale B, Hounmanou G, BabaMoussa L, et al. Évaluation de la performance de trois marques de disques d'antibiotiques vendues au Benin. Heal Sci Dis. 2016;17:71-8. French.

31. Hou XH, Song XY, Ma XB, Zhang SY, Zhang JQ. Molecular characterization of multidrug-resistant Klebsiella pneumoniae isolates. Braz J Microbiol. 2015;46(3):759-68. doi: 10.1590/S1517-838246320140138. [PubMed: 26413058]. [PubMed Central: PMC4568872].

32. Belbel Z. Evaluation de la résistance aux antibiotiques des souches de Klebsiella pneumoniae isolées dans les hôpitaux de la ville d'Annaba. University Badji Mokhtar Annaba; 2013. French.

33. Kamga HG, Nzengang R, Toukam M, Sando Z, Shiro SK. Phénotypes de resistance des souches d'Escherichia coli responsables des infections urinaires communautaires dans la ville de Yaoundé (Cameroun). Afr J Pathol Microbiol. 2014;3:1-4. French.

34. Salah DF. Détermination de gènes de résistance codant pour les BêtaLactamases à Spectre Elargie (BLSE) chez les Entérobactéries à Lomé, TOGO. University Ouagadougou; 2015. French.
35. Diagbouga S, Salah DF, Sadji A, Dabire MA, Nadembega C, Kere B et al. Detection of high prevalence of TEM/SHV/CTX-M genes in ESBL producing and multidrug resistant Klebsiella pneumoniae and klebsiella oxytoca. JBRJ Clin Diagnosis Res. 2016;4:1-7.

36. Albrechtova K, Kubelova M, Mazancova J, Dolejska M, Literak I, Cizek A. High prevalence and variability of CTX-M-15-producing and fluoroquinolone-resistant Escherichia coli observed in stray dogs in rural Angola. Microb Drug Resist. 2014;20(4):372-5. doi: 10.1089/mdr.2013.0177. [PubMed: 24568119].

37. Ewers C, Bethe A, Stamm I, Grobbel M, Kopp PA, Guerra B, et al. CTXM-15-D-ST648 Escherichia coli from companion animals and horses: Another pandemic clone combining multiresistance and extraintestinal virulence? J Antimicrob Chemother. 2014;69(5):1224-30. doi: 10.1093/jac/dkt516. [PubMed: 24398338].

38. Ben Slama K, Ben Sallem R, Jouini A, Rachid S, Moussa L, Saenz Y, et al. Diversity of genetic lineages among CTX-M-15 and CTX-M-14 producing Escherichia coli strains in a Tunisian hospital. Curr Microbiol. 2011;62(6):1794-801. doi: 10.1007/s00284-011-9930-4. [PubMed: 21479796].

39. Lohr IH, Rettedal S, Natas OB, Naseer U, Oymar K, Sundsfjord A Long-term faecal carriage in infants and intra-household transmission of CTX-M-15-producing Klebsiella pneumoniae following a nosocomial outbreak. J Antimicrob Chemother. 2013;68(5):1043-8. doi: 10.1093/jac/dks502. [PubMed: 23288401].

40. Haenni M, Saras E, Ponsin C, Dahmen S, Petitjean M, Hocquet D, et al. High prevalence of international ESBL CTX-M-15-producing Enterobacter cloacae ST114 clone in animals. J Antimicrob Chemother. 2016;71(6):1497-500. doi: 10.1093/jac/dkw006. [PubMed: 26850718].

41. Bachiri T, Bakour S, Ladjouzi R, Thongpan L, Rolain JM, Touati A. High rates of CTX-M-15-producing Escherichia coli and Klebsiella pneumoniae in wild boars and Barbary macaques in Algeria. J Glob Antimicrob Resist. 2017;8:35-40. doi: 10.1016/j.jgar.2016.10.005. [PubMed: 27984780].

42. Newire EA, Ahmed SF, House B, Valiente E, Pimentel G. Detection of new SHV-12, SHV-5 and SHV-2a variants of extended spectrum betalactamase in Klebsiella pneumoniae in Egypt. Ann Clin Microbiol Antimicrob. 2013;12:16. doi: 10.1186/1476-0711-12-16. [PubMed: 23866018]. [PubMed Central: PMC3723734].

43. Nicolas-Chanoine MH, Gruson C, Bialek-Davenet S, Bertrand X, Thomas-Jean F, Bert F, et al. 10-Fold increase (2006-11) in the rate of healthy subjects with extended-spectrum beta-lactamase-producing Escherichia coli faecal carriage in a Parisian check-up centre. J Antimicrob Chemother. 2013;68(3):562-8. doi: 10.1093/jac/dks429. [PubMed: 23143897].

44. Lagha N. Dédicaces. University Abou Bekr Belkaïd Tlemcen; 2015. [dissertation]. French.

45. Zurfluh K, Nuesch-Inderbinen M, Morach M, Zihler Berner A, Hachler H, Stephan R. Extended-spectrum-beta-lactamase-producing Enterobacteriaceae isolated from vegetables imported from the Dominican Republic, India, Thailand, and Vietnam. Appl Environ Microbiol. 2015;81(9):3115-20. doi: 10.1128/AEM.00258-15. [PubMed: 25724954]. [PubMed Central: PMC4393435]. 